\title{
Celebrating more women leaders in global health
}

Cite as: CMAJ 2017 November 20;189:E1433-4. doi: 10.1503/cmaj.109-5520

Posted on cmajnews.com on Oct. 30, 2017.

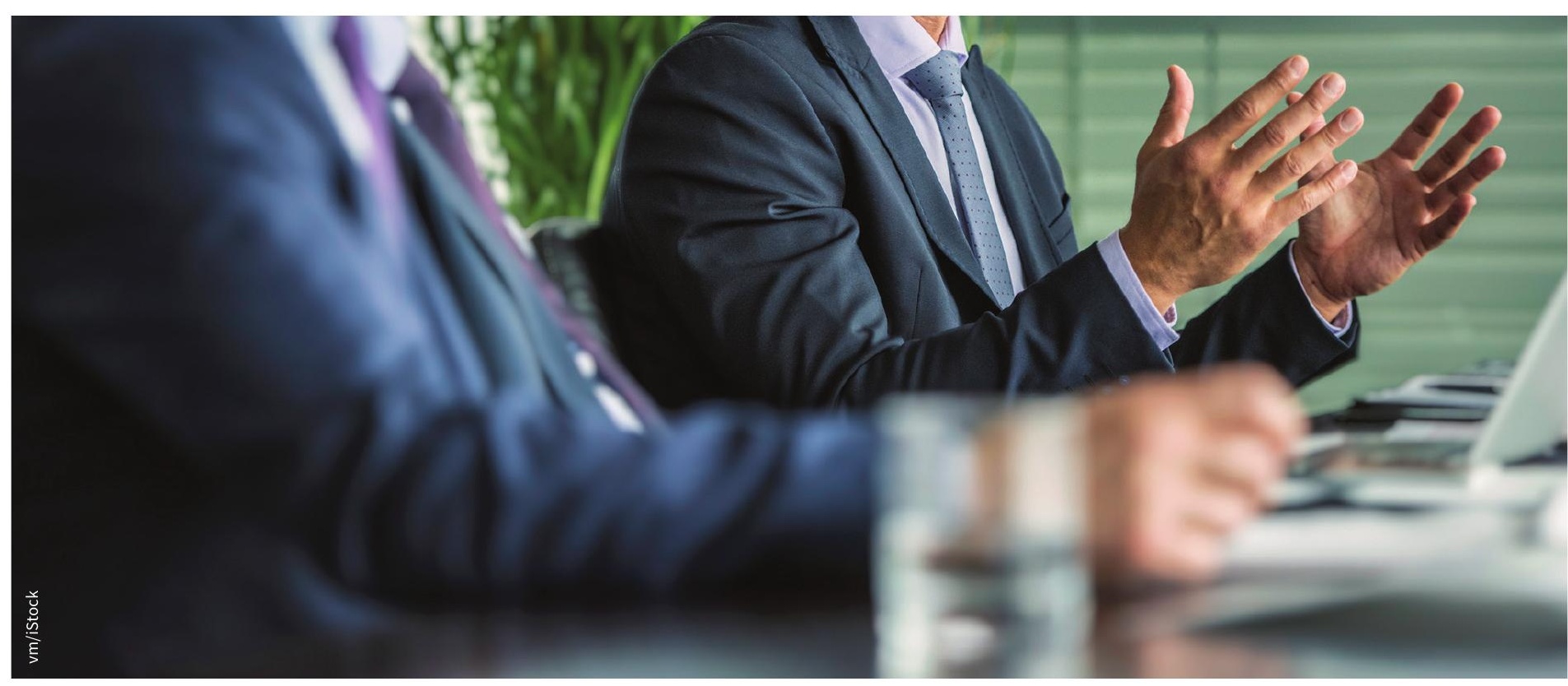

There's still a glass ceiling in global health leadership, but cracks are starting to show.

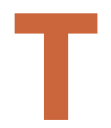
he World Health Organization (WHO) recently announced an unprecedented change in its senior leadership - seven of 11 top positions at the organization are now held by women. The change is striking because it's so rare, said speakers at the inaugural Women Leaders in Global Health conference, held at Stanford University in California and attended by some 400 people from 68 countries.

At least $75 \%$ of the global health workforce is female, as are the majority of caregivers and the most vulnerable patients. But with every step up the ladder, the proportion of women shrinks, said Dr. Michele Barry, director of Stanford's Center for Innovation in Global Health.
"It's a room full of men discussing women's health."

Most health care administrators, health-sector CEOs, deans, ministers of health and members of the World Health Assembly are men. WHO has been led by a woman twice, UNICEF just once, and the United Nations and World Bank have never had female leaders.

There's no shortage of talented women in the pipeline, and studies show that diversity benefits everyone, Barry said. "Careers flourish, companies prosper and outcomes improve."

But women who do advance into senior positions are often "undervalued, unacknowledged and undercompensated," said Afaf Meleis, dean of nursing emeritus at the University of Pennsylvania.
How we define leadership is part of the problem, she explained. Female leaders abound in nursing and midwifery, but global health leadership has been defined by doctors and deans of medicine. "When we expanded it a little bit, we added economists and we added lawyers."

Although more women are joining these fields, they face substantial bias and barriers to advancement. A recent study found that the average female physician in America earns 27\% less than her male peers, even in specialties that are predominately female, such as pediatrics. Speakers at the conference also shared evidence that researchers with female or unisex names are less likely to receive grants than those with male names. 
It's not a matter of women being less qualified, said Veronica Magar, WHO director for gender, equity and human rights. "Gender parity is possible if we're prepared to admit that there are talented women around us; the problem is that we don't admit they exist."

Powerful men have a role to play by mentoring and promoting women, said Dr. Peter Piot, director of the London School for Hygiene and Tropical Medicine. "There's the reality that in order to achieve gender parity, men have to give up something."

According to Dr. Agnes Binagwaho, former health minister of Rwanda, progress won't be sustained without institutional and legal changes to require a certain percentage of women in senior positions. "If you don't do positive discrimination in favour of women, you don't get there."
In 2003, Rwanda introduced a new constitution mandating that women hold $30 \%$ of positions in government, including parliament. It's now the only country in the world where more women than men serve as elected officials.

At first, it was difficult to fill the positions because "education of women was not equal," said Binagwaho. But because representation was mandatory, the government was compelled to address those gaps.

She also warned against the tendency to "applaud and forget" the need for systemic change when an organization hires token leaders. "Most of these institutions are putting women there just to show that they're good."

When Dr. Glenda Gray became the first female president of the South African Medical Research Council, she found that the organization had never analyzed who it was funding. As it turned out, "the majority of people we funded were white men from Ivy League universities," said Gray.

The revelation prompted an overhaul of the granting system, including splitting the competition into different career stages, and giving additional weight to African and female scientists, as well as to historically disadvantaged institutions. The organization also changed the age cut-off for the early-stage investigator competition, because they found that most women entered research in their forties, after marriage and babies.

Five years later, "the majority of people who get funding now are black African scientists and 50\% are women," Gray said. The next step is growing the next generation of leaders, particularly black female scientists. "Everybody has talent and our job is to make their talent show."

Lauren Vogel, CMAJ 